\title{
The concept of money laundering: a quest for legal definition
}

\author{
Muhammad Saleem Korejo
}

Business Administration Department, Sukkur IBA University, Sukkur, Pakistan and Faculty of Law, National University of Malaysia, Bangi, Malaysia, and

Ramalinggam Rajamanickam and Muhamad Helmi Md. Said Faculty of Law, Universiti Kebangsaan Malaysia, Bangi, Malaysia

\begin{abstract}
Purpose - This paper aims to focus on the concept of money laundering and explores the evolution and expansion of criminalization of predicate offences to the money laundering within the international anti-money laundering (AML) regime over the time. It proposes how to limit the size and scope of predicate offences in designing a balanced legal definition.
\end{abstract}

Design/methodology/approach - This paper opted a content analysis focussed on the criminalization aspect of offences to money laundering in the international AML regime under the United Nations Conventions (Vienna, Palermo and Corruption Convention) and Financial Action Task Force Standards.

Findings - This paper provides how the criminalization of money laundering has evolved and its definition expanded over the time. The international definition is widely drafted with wide range of predicate offences from proceeds of drug money to corruption, including terrorist financing and terrorist acts; however, the two phenomena - money laundering and terrorist financing are quiet distinct apart. This continual expansion of predicate offences quite leads legality issues such as over-criminalization and conflict with principles of criminal law. This paper suggests an approach to limit the size and scope of predicate offences to money laundering.

Practical implications - This paper includes implications for the development of a balanced approach in defining predicate offences through a qualitative limitation approach consistent with the minimalist theory of penalization of criminal law.

Originality/value - This paper attains an identified issue how the legal definition of the money laundering offence can be improved while considering rule of law and principles of criminal law concerns.

Keywords Money laundering, Proceeds of crime, Predicate offence, FATF, AML, Legal definition

Paper type Research paper

\section{Introduction}

The issue of money laundering came to the surface following incidents like the Panama repots, the Paradise Papers, the Swiss leaks and other journalistic investigations, which highlighted the part played by offshore entities in global money laundering programmes, which raised global voices for the conceptualization and implementation of effective counter money laundering programmes. Money laundering is the process of conversion of illicit

(C) Muhammad Saleem Korejo, Ramalinggam Rajamanickam and Muhamad Helmi Md. Said. Published by Emerald Publishing Limited. This article is published under the Creative Commons Attribution (CC BY 4.0) licence. Anyone may reproduce, distribute, translate and create derivative works of this article (for both commercial and non-commercial purposes), subject to full attribution to the original publication and authors. The full terms of this licence may be seen at http:// creativecommons.org/licences/by/4.0/legalcode
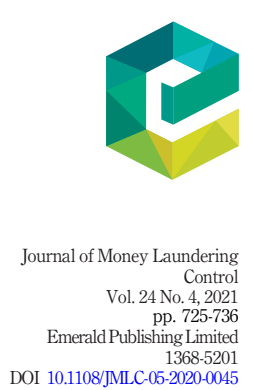
money which comes out of the crime which is then intermixed with the licit money to make appear legitimate, and it becomes very difficult to distinguish the legitimate money from the illegitimate one. Efforts to criminalize money laundering first appeared under international law in 1988 with the Vienna Convention of the United Nations and the main reason behind criminalization was to prevent entrance of crime proceeds in the legitimate economy. Considering the fact that, scholarship has allocated themselves to the issue and the academic discourse reached at its peak following the events of 9/11 terrorist attacks and the global leaks. A sizable part of global AML law regime talked also the funding for terror activities; however, this article focuses instead on the concept of money laundering as the fact relevant to illicit proceeds, organized and financial crime; which rotates around its precursor concept of proceeds of crime. For over 30 years the narrative has been that the criminalization of money laundering was to deter and tackle serious crime, organized crime and to preserve the integrity of global financial setup (Zoppei, 2015). Certainly, Criminal law generally requires a value to protect; either be an integrity of a financial system, national security or public order; however, criminal law endeavours to tackle with organized and serious crime because the concept is not of an easy definition, even it becomes more complex when it constitutes crime proceeds (Sergi, 2015). However, scholarship has been critical of the AML legal regime, arguing that such legal regime has not attained their targets yet (Pol, 2018; Jayasekara, 2018; Slot and Swart, 2019; Pol, 2020), whereas much has been discussed in the literature about the prevention of money laundering, development of AML regimes and their impact. There are some studies taken on the criminological aspects of money laundering and predicate offences (Islam et al., 2017; Rusanov and Pudovochkin, 2018; Paunović, 2019). One important study titled "broadly defined ambit of money laundering offences globally, a recipe for confusion than clarity?" (Mugarura, 2016a) highlights the development and expansion of money laundering predicate offences; however, the study is tilted on the complexities of financial crimes and the work is more on the UK and USA jurisdictions. This paper, however, attempts to uncover legality issues such as over-criminalization and conflict with principles of criminal law.

The article starts with a general definition of money laundering describing the phenomenon as a process of converting illicit income and discusses the concept in its legal sense under the prism of relevant United Nations Conventions, European Union Council Directive and some jurisdiction like UK, USA and Pakistan. The emphasis will be given on the proceeds of crime-element of money laundering while discussing criminological features of money laundering. The second part of article traces how the criminalization of money laundering has evolved globally and the definition of money laundering has expanded over the time. The third part debates the controversial criminal law issues raised by addition of predicate offences to the definition of money laundering offence and finally concludes with an approach to reform the definition.

\section{The concept of money laundering}

Money laundering (ML) is a generic term used to expound a process by which criminals launder their dirty money into a clean money, thus, cover up their proceeds of criminal conduct and their sources to make it to appear legitimate. It is not a new concept, it has been in practice since ages, when $\mathrm{Al}$ Capone deployed launderettes to hide illicit gains procured from selling bootleg (Unger, 2013), thus, is a process by which criminals attempt to stash the actual origin or source of their illegitimate income. ML is a willful and complex process whereby the proceeds of crime are cached and well ordered to look as they were acquired through legal means. The process has three main phases firstly, the black or soiled money must be sliced from the predicate offence; secondly, the money chain must be made 
mysterious or destroyed so as to avoid discovery; and lastly, the proceeds of such crime are re-injected into further business activity to launder it (Mugarura, 2016b). As a result of this complexity and the development of the processes of globalization the concept of ML has transverse relationship with criminal, administrative, financial and international public law. In the work of (Vervaele, 2013) the ambit of derivative offences is no longer confined to drug money, rather has extended to organized crimes, serious crimes and terrorism due to transnational feature of the crime. This further expansion to the financing of terrorism, the focus has not been limited to the illicit money of criminality; it also extends to the legal and illegal funds thus making the concept more complicate under criminal law perspective. Although, intent of many national legislatures behind criminalization of ML was to combat drug trafficking; however, international AML regime pushed the nations in adoption of new predicate offences to the offence of ML which consequently lead for broadening the extent of the offence (Zoppei, 2017). This push created an urgency to devise legislative and administrative AML strategies symmetrized across jurisdictions with primary aim to criminalize ML and its derivative offences, while leaving legal concerns in their respective AML frameworks including administrative and criminal law measures and protection of individual rights, data protection and privacy issues (Bergström, 2018).

As mentioned earlier, ML is a set of behaviours of action which constitute a crime; however, ML per se is not a crime. Therefore, the following section attempts to uncover the exiting-legal definition of ML prevalent in the contemporary AML jurisdictions.

\section{Money laundering: the legal definition}

The expression money laundering surfaced in 1973 in USA, in the period of Watergate Scandal; however, the word was informally used to describe a process to transform money from black to white; therefore, it has no legal definition but a colloquial phrase (Schneider, 2008). A supranational definition of money laundering was formulated by the United Nations Convention against Illicit Traffic in Narcotic Drug and Psychotropic Substances 1988 and was almost followed by global community although restricted to the drug related proceeds of crime.

In a broader assessment of the crime, the United Nations Convention against Transnational Organized Crime (Palermo Convention) outlines ML as "the conversion or transfer of property, knowing that such property is the proceeds of crime, for the purpose of disguising the illicit origin of the property or of helping any person who is involved in the commission of the predicate offence to evade legal consequences of his/her action; the concealment or disguise of the true nature, source, location, disposition, movement or ownership of or rights with respect to property, knowing that such property is the proceeds of crime; the acquisition, possession or use of property, knowing at the time of receipt that such property is the proceeds of crime; participation in, association with or conspiracy to commit, attempt to commit and aiding and abetting, facilitating and counselling the commission of any of the offences established in accordance with this article (Drugs and Crime, 2004; Bar-ness, 2014)".

Under European Union Council Directive: (Directive, 1991) "Money laundering` means the following conduct when committed intentionally:

- The conversion or transfer of property, knowing that such property is derived from criminal activity or from an act of participation in such activity, for the purpose of concealing or disguising the illicit origin of the property or of assisting any person who is involved in the commission of such activity to evade the legal consequences of his action. 
JMLC 24,4

\section{8}

- The concealment or disguise of the true nature, source, location, disposition, movement, rights with respect to, or ownership of property, knowing that such property is derived from criminal activity or from an act of participation in such activity.

- The acquisition, possession or use of property, knowing, at the time of receipt, that such property was derived from criminal activity or from an act of participation in such activity.

- Participation in, association to commit, attempts to commit and aiding, abetting, facilitating and counselling the commission of any of the actions mentioned in the foregoing paragraphs. Knowledge, intent or purpose required as an element of the abovementioned activities may be inferred from objective factual circumstances. ML shall be regarded as such even where the activities which generated the property to be laundered were perpetrated in the territory of another Member State or in that of a third country."

In UK, ML is an offence under section 327 of the Proceeds of Crime Act (2002) (POCA), "A person commits an offence if he or she conceals, disguises, converts or transfers criminal property or removes it from England and Wales or Scotland or Northern Ireland; enters into or becomes concerned in an arrangement which he or she knows or suspects facilitates the acquisition, retention, use or control of criminal property; acquires, uses or has possession of criminal property." Besides this, section 329 of POCA also includes acquisition, use and possession of criminal property under the ambit of the offence of money laundering. Importantly, section 330 of the POCA outlines stipulations and attracts ML liability to a person where he fails to report a suspicious activity to the regulator sector (banks and financial institutions).

In the context of USA, under section 1956 of US Code 18: "Whoever, knowing that the property involved in a financial transaction represents the proceeds of some form of unlawful activity, conducts or attempts to conduct such a financial transaction which in fact involves the proceeds specified unlawful activity: with the intent to promote the carrying on of specified unlawful activity; or with intent to engage in conduct constituting a violation of section 7201 or 7206 of the Inland Revenue Code of 1986; or knowing that the transaction is designed in whole or in part to conceal or disguise the nature of, the location, the source, the ownership or the control of the proceeds of specified unlawful activity; or to avoid transaction reporting requirement under State of Federal Law."

However, under section 3 of the AML Act (2010) (AMLA), of Pakistan, it is an offence and "a person is guilty of the crime who acquires, converts, possesses, use or transfer of property, knowing or having reason to believe that such property is proceeds of crime; conceals or disguises the true nature, origin, location, disposition, movement or ownership of property, knowing or having reason to believe that such property is proceeds of crime; holds or possesses on behalf of any other person any property knowing or having reason to believe that such property is proceeds of crime; or participates in, associates, conspires to commit, attempts to commit, aids, abets, facilitates, or counsels the commission of the acts specified above."

All above-mentioned denotations, however, appear valid; centered on income, property, illicit proceeds and unlawful activities largely anchored to criminal aspects. Yet, such a proposal is a deficient definition of the concept of ML, resulting in an ill-suited appreciation of the ML process. An appraisal of these conventional definitions of ML exhibits that they are action oriented and while still include plenty of lawful actions. Apparently, all of the above-mentioned definitions of $\mathrm{ML}$ almost cover any type of conduct with "proceeds of 
crime" falling within the range of "money laundering" and consequently made culpable. However, the ambit of "proceeds of crime" is too wide. Therefore, an insight of the sphere of "proceeds of crime" is essential to the understanding of the crime of "money laundering."

\section{Concept of money laundering}

\section{Money laundering: proceeds of crime}

The word proceeds of crime generally denotes to money or asset(s) acquired by criminals in the course of their criminal activity. In the meaning of United Nations Convention against Illicit Traffic in Narcotic Drugs and Psychotropic Substances (1988) (UN Drug Convention or Vienna Convention) "Proceeds" means any kind of asset formed of generated either directly or indirectly, through the commission of an offence established in accordance with paragraph 1 of the Article 3, which covers offenses related to drug, and the term "Property" means "assets of every kind, whether corporeal or incorporeal, movable or immovable, tangible or intangible and legal documents or instruments evidencing title to, or interest in, such assets." It simply means "proceeds are the property derived from" the manipulation of drug crime. However, in the content of UN-Palermo and Convention against Corruption, the sphere of "proceeds" is widened beyond drug-related proceeds to serious crimes like bribery, embezzlement, concealment of property and corruption thus expanding the ambit of ML to a wider extent with inclusion of serious and predicate offences.

Under section 2 of the AMLA 2010 of Pakistan, "proceeds of crime" includes property of every kind generated directly or indirectly from the commission of a predicate or a foreign serious offence, and a "predicate offence" are categorized list of offences specified in the Schedule to AMLA 2010; whereas, "foreign serious offence" is: "(i) against the law of a foreign State stated in a certificate issued by, or on behalf of, the government of that foreign State; and (ii) which, had it occurred in Pakistan, would have constituted a predicate offence." The same section further defines "property" in a same manner as defined under Article 3 of UN Vienna Convention encompassing cash and instruments irrespective of its location. Most importantly, AMLA has an additional definition of the term "property involved in money laundering" have the same meaning that is of the "proceeds of crime."

From the previously mentioned detail, it clearly exhibits that proceeds come out of any criminal activity either serious or inferior; however, it is seriousness of the crime that link such proceeds to offence of money laundering. It is thus, pertinent to uncover criminological aspects of money laundering.

\section{Criminological features of money laundering}

After the examination of the definition of "proceeds of crime" under international and domestic law, it may be broken down to essentially refer to three types of properties. First, property generated as a consequence of criminal conduct relating to a specified offence. Second, value of the property in question and last, property equivalent in value retained within the country and where such property is taken or kept outside the country. Meaning that, ML constitutes the intended generation of all monetary and non-monetary assets, obtained directly or indirectly from any criminal conduct; the former refers to hard-cash or in soft-electronic bank transfers or their substitutes and the latter includes moveable goods and immoveable estates. Moreover, such criminal conduct is intended for realization of asset. Thus, actions are characterized by a criminal intent to methodically convert, mix, conceal and deceive the true source or nature of objects involved on the criminal activity.

As mentioned earlier, that there has been continual extension of the derivative offences to the offence ML thus, it is vital to explore this evolving global legal framework combating money laundering. 


\section{Quest for legal definition: evolution of global legal framework on money laundering}

For over 30 years, the world community has evolved an extensive AML legal framework. The development of this framework has been associated with the United Nations Vienna Convention of 1988, centered on the issue of laundering of the proceeds of drug trafficking. Following this, the Convention on Transnational Organized Crime, or the Palermo Convention of 2000 and the Convention against Corruption in 2003, collectively extended derivative offences relevant to offence of ML. All three Conventions thus, provided the foundation of contemporary global framework on combating money laundering. However, more crucial to the growth of the international AML law regime has been the efforts of the Financial Action Task Force (Force, 2012).

\section{United Nations convention against illicit traffic in narcotic drugs and psychotropic substances 1988}

The United Nations Convention against Illicit Traffic in Narcotic Drugs and Psychotropic Substances (1988) (Vienna Convention) is a first inter-governmental agreement to criminalize money laundering, however, confined to drug related crime such as production, cultivation, purchase, exchange, possession and management of drug or psychotropic substance. The instrument also required states to adopt uniform AML laws such as freeze and forfeiture of any illegal proceeds across the world. However, the Convention did not explicitly introduce the term "Money Laundering." Yet, this instrument provided an extensive definition of the "proceeds" of drug related crimes and was a holistic tool to counter modern international drug trafficking, it put obligation on states to criminalize laundering of drug related proceeds and deemed ML an extraditable offence. Under this instrument "proceeds" deemed any property derived or obtained, directly or indirectly through the commission of the offences related to drug (as mentioned in paragraph (a) of the Article 3 of the Convention). Further the ambit of offence also included the offence of participation in hiding or camouflaging the illegal origin or source of the property (drug proceeds). Besides this, the offence of assisting any person in the commission of such an offence or offences to evade the legal consequences of his actions also constitute ML; assisting mean, any act of concealment or camouflage of the true origin, disposition, movement, of property, knowing that such property is obtained from an offence or offences established in accordance with Article 3 of UN Vienna Convention.

However, the criminalization efforts under Vienna Convention recognized the proceeds of drug related offences, yet it had main lacuna of wordings with respect to money laundering. Although it was specific to drug associated ML in scope and application. The income produced from other offences were yet free to be laundered, thus, fall within instrument's blind spot.

\section{United Nations convention against transnational organized crime 2000}

The United Nations Convention against Transnational Organized Crime (Palermo Convention) is a multilateral treaty against international organized crime and was adopted in 2000 in Palermo. However, it entered into force on 29 September 2003. The Convention designed for the promotion of co-operation among countries to prevent and combat transnational organized crime more effectively. The Convention was first international binding instrument in the area of international organized crime. The Palermo Convention expanded the criminalization sphere of "proceeds of crime" from drug related offences to proceeds of "serious offence" where penalty for the crime is maximum deprivation of liberty for or above four years. Moreover, under this Convention, an important evolution occurred 
in the offence of ML by criminalization to a variety of predicate offences, which include all serious offences, involvement in an organized criminal groups, participation as an accomplice, corruption, restricting justice and involvement of legal persons in serious offences.

Although, the Convention is a holistic instrument which designs a founding structure for dealing the issue of ML and proceeds of crime; however, it has certain deficiencies in terms of vagueness in concepts such as "serious offence" and no description of term "predicate offence." The convention also has certain shortcomings related to corruption and corrupt practices offences.

\section{United Nations convention against corruption 2003}

The United Nations Convention against Corruption was adopted in 2003 and entered into force in 2005. It is a multilateral and legally binding anti-corruption treaty as stated by (Chaikin and Sharman, 2009), the relationship between corruption and ML is symbiotic in nature: presence of one incline to bring and reciprocate the occurrence of the other crime. This instrument retained the concept of "predicate offence" from its preceding Convention; however, it further expanded the area of ML offence to bribery, embezzlement, misappropriation, trading in influence, illicit enrichment and abuse of functions by public office holders. However, "predicate offence" defined as any offence as a result of which proceeds have been generated and are subject of an offence of laundering. Notably, the Convention requires nations to apply "widest possible range" of predicate offences which includes both within and outside jurisdictions in respective legal regimes this further expands the ambit of money laundering. Apart from laundering of proceeds of crime under Article 23, the Convention further extends criminal liability without having participated in such offences (predicate) to the "Concealment or continued retention of property when the person involved knows that such property is the result of any of the offences established in accordance with this Convention."

In addition to this, the Convention requires countries to incorporate a holistic domestic regulatory and supervisory mechanism for financial and non-financial institutions to detect and deter ML in all its manifestations and to devise strategy to check the cross-border filtration of money. The instrument also requires to promote regional and bilateral cooperation in the fight against ML which includes collaborations among law enforcement, regulatory bodies and the judicial matters. Although, this convention further expanded the sphere of AML by widening definition of ML offence to proceeds of all serious crimes, besides illicit trafficking and did not provide any guidelines or description relevant to inclusion of "all serious crime" approach in the definition of ML offences.

\section{Financial action task force}

The FATF is an inter-governmental body and was formed in 1989 G-7 Summit in Paris, to devise and promote standards for AML and Combating Financing of Terrorism (CFT). FATF is the main muscle that is maintaining the fight against ML worldwide therefore, is a "policymaking" body that works to generate the necessary political will to bring about legislative and regulatory reforms. In line with its mission, it has developed globally recognized standards for processes, procedures, regulation and monitoring of ML activities called "Recommendations" to inhabit ML, CFT and misuse of financial institutions by persons laundering drug money. Since 1990, these "Recommendations" were revised and updated in 1996, 2001 and 2003 and in 2012 so as to combat the crime effectively due to its evolving techniques. There have been updates in February 2013, October 2015 and June 2016, respectively. The FATF Recommendations are not an international law; however, they 
JMLC 24,4

reflect in the substance and policies of the UN conventions and UN Security Council resolutions (Stessens, 2000). Therefore, these recommendations are adopted by key international organizations, including International Monetary Fund, World Bank (WB) (Gordon, 2010) and are also endorsed by the United Nations Security Council (UNSC) in 2005 through its Resolution 1617 (Williams, 2016). The FATF has also devised a mechanism of "mutual evaluations and self-assessments" (Jensen and Png, 2011) to monitor the progress of its members through reviewing ML and terrorist financing counter measures. Until now, FATF has been the major rule-making body in the field of combating ML/TF, a great deal of jurisdictions and organizations have incorporated its recommendations. Generally, FATF has been viewed a successful in maintaining rule-setter. Empirical study demonstrates that international bodies inflict sanctions to exert pressure, similarly FATF uses "grey list" and "black list" solely to push states to cooperate (Kerwer and Hülsse, 2011).

FATF recommendations are admixture standards of criminal justice system and financial regulatory system along with global cooperation against the war on ML. While, in the efforts against criminalization of $\mathrm{ML}$ these recommendations went beyond drug trafficking to include other predicate offences to the offence of ML. However, the definition containing the main elements has remained same as of UN Vienna and Palermo Convention, the area which has developed gradually is the expansion of predicate offences-crimes that are deemed to give rise proceeds. This increase in the directory of predicate offence reflects the examination of ML as an ever-changing threat (Mitsilegas and Vavoula, 2016).

\section{Predicate offence expanding scope and size}

As acknowledged earlier, the evolvement of global AML legal regime has shown a continual widening of the directory of ML predicate offence, so did many jurisdictions in their national legislation. Legislators justified the expansion of the scope of predicate offence accompanied by the rational that this measure was essential to guard the legitimate economy from manipulation of funds of criminal source thus, the objective to defend the financial system from being abused. This aim, however, has not yet achieved (Pol, 2018; Jayasekara, 2018; Slot and Swart, 2019; Pol, 2020). This multifaceted use of the offence of ML has raised legal challenges which may hamper the successful implementation of the law.

Firstly, so far there is no any symmetry across jurisdictions on the concerns secured by the offence of ML. It is noticed that many nations have differences of understanding of the purposes of AML laws; some perceive it as a policy of anti-terrorism and CFT, some consider it as a tool against tax evasion, and others regard as a device to anti-corruption (Unger et al., 2014). Many jurisdictions have included distinct approaches: several contemplate ML as an offence relevant to property crime; while others have placed it the list of crimes against dispensing justice; still others associate criminalizing ML a tool to protect the interest of the financial sector (Mitsilegas, 2003).

Secondly, the widening list of predicate offences was made without considering a sufficient discourse on the criminal law principles in dealing with the concept of ML. The Palermo convention imposes obligation upon all States to apply ML offences "to the widest range of predicate offences." The earlier version of FATF Recommendation 3 outlined, the predicate offences have to be "based on serious offences." Importantly, neither of UN Conventions nor previous versions of FATF Recommendations did define what constitutes the "widest range" and what is "serious offence", whereas, in the updated version of FATF Recommendation 3 the scope of the predicate offences is described with reference to "all serious offence" approach and "threshold approach"- that all offences punishable by imprisonment of more than one year or where minimum threshold for crimes in minimum of six months respectively. Under the same recommendation countries are left with option to 
opt for either of the two approaches or of mixture of both as per their legal system. Additionally, the recommendations requires "as a minimum" countries should cover "a range of predicate offence" in each of twenty "designated" categories of offence. Moreover, there is no guideline about "how to define designated offence and the nature of any particular elements of those offences make them ML predicate offences. The propensity to increase the list of predicate offences and requirement of minimum penalty limit in delineating "serious offence"-minimum imprisonment order to regard an offence a "serious offence", to six months specially across European jurisdictions, and the unclear definition of

Concept of money laundering

733 actus reus: a key constituent component of a crime in establishing the ML crime, may result to "an unlimited power of prosecution and punishment" (Mitsilegas, 2003).

Thirdly, a further extension is noticed by FATF which precisely necessitate funding for terror, terrorist activities and organizations involved in terrorism be "designated" ML predicate offence. So far, the two concept completely different of each other; one having motive to generate and mix funds from illicit activities while the other being to infuse terror at large. Yet, the funds in financing terrorism may come from legitimate sources like charities, salaries of individuals and gifts (Irina, 2017) which is exact anti-thesis of the essence: "proceeds of crime" of the definition of the offence of ML thus, financing terrorism may not necessarily qualify the definition of ML. Further, this inclusion of terror financing in AML regime may prove unsuccessful by using AML tools for dealing terrorism a completely different concept.

Lastly, FATF has followed the course of widening the circle of predicate offences to ML by expressly including a tax crime in the list of "designated" offences. This tax crime regards with both direct and indirect taxes yet, there is no any consensus on a harmonized definition of tax crime at global level. This explicit addition of tax offences may result to an undifferentiated crime control approach of "catch-all" which on one side, fails to determine the rationale behind criminalization of this crime and on the link between serious and organized crime on the side. Under the lens of criminal law, this "catch-all" approach by inserting tax predicates may compromise criminal law principles (Mitsilegas et al., 2015) and hold "unfair labelling" of the offense (Alldridge and Mumford, 2005).

Notably, the influence of FATF Standards on shaping global AML regime is raising questions, FATF being an ad hoc-task force with particular membership having less accountability and transparency in its operations (Cohen and Sabel, 2004). The magnitude with which it influences AML legislative choices may result over-criminalization and also raises concerns pertaining the observance of legal principles across jurisdictions (Husak, 2008).

\section{Conclusion}

Since the adoption of UN Vienna Convention, there has been continual quest for a much extensive legal definition of ML depended on a "wide range of predicate offences," this can be referenced to the Palermo Convention and FATF Recommendations since 1996. The global AML framework is constantly developing and expanding, efforts have been made to regularly revise and widen the criminalization of offences to money laundering. There has been observed a multiplication of predicate offences and merger of terrorist financing, terrorist acts and tax offences within global AML regime, however, the two phenomenonmoney laundering and terrorist financing are quiet distinct apart. This continual expansion of predicate offences quite lead legality issues such as over-criminalization and conflict with principles of criminal law. Above all, the rule setting role of FATF being an ad hoc entity over global AML framework acts to distant the global political deliberations on the need for AML efforts. With respect to limiting the size and scope of predicate offence, rather on "all 
crime approach" or "threshold approach", it is proposed to penalize the laundering of proceeds of any crime through insertion of quantitative limitation clause that, when the property involved in the generation of proceeds of crime exceeds a substantial economic value either in a single act or through repetition of related acts. This perspective is also consistent with the minimalist theory of penalization of criminal law. Further, the seriousness of the predicate offence must be gauged on the basis monetary value. It is also highly recommended that global community under the Umbrella of United Nations must discuss and devise a uniform definition of the concept of ML by taking in account the key principles of criminal law.

\section{References}

AML Act (2010), Pakistan.

Alldridge, P. and Mumford, A. (2005), "Tax evasion and the proceeds of crime act 2002”, Legal Studies, Vol. 25 No. 3, pp. 353-373.

BAR-Ness, G. (2014), "United nations crime conventions”, The Encyclopedia of Criminology and Criminal Justice, Vol. 1, pp. 1-6.

Bergström, M. (2018), "The many uses of AML regulation - over time and into the future", German Law Journal, Vol. 19 No. 5, pp. 1149-1167.

Chaikin, D. and Sharman, J. (2009), Corruption and Money Laundering: A Symbiotic Relationship, Springer, New York, NY.

Cohen, J. and Sabel, C.F. (2004), "Global democracy”, NYUJ International Law and Policy, Vol. 37, p. 763.

Directive, C. (1991), "91/308/EEC of 10 June 1991 on prevention of the use of the financial system for the purpose of money laundering", Official Journal of the European Union, Vol. 166, pp. 77-83.

Drugs, U.N.O.O. and Crime, (2004), "Report of the conference of the parties to the united nations convention against transnational organized crime on its first session", Held in Vienna From 28 June to 8 July 2004.

Force, F.A.T. (2012), The FATF Recommendations: International Standards on Combating Money Laundering and the Financing of Terrorism and Proliferation, FATF, Paris, February.

Gordon, R.K. (2010), "Losing the war against dirty money: rethinking global standards on preventing money laundering and terrorism financing", Duke Journal of Comparative \& International Law, Vol. 21, p. 503.

Husak, D. (2008), Overcriminalization: The Limits of the Criminal Law, Oxford University Press, Oxford.

Irina, I. (2017), "Finanțarea terorismului Și spălarea De bani (financing terrorism and money laundering)", available at SSRN 3006005.

Islam, M.S., Eva, S.A. and Hossain, M.Z. (2017), "Predicate offences of money laundering and anti money laundering practices in Bangladesh among South Asian countries", Studies in Business and Economics, Vol. 12 No. 3, pp. 63-75.

Jayasekara, S.D. (2018), "Challenges of implementing an effective risk-based supervision on AML and countering the financing of terrorism under the 2013 FATF methodology", Journal of Money Laundering Control, Vol. 1.

Jensen, N. and Png, C.-A. (2011), "Implementation of the FATF 40+ 9 recommendations: a perspective from developing countries", Journal of Money Laundering Control, Vol. 14 No. 2, pp. 110-120.

Kerwer, D. and Hülsse, R. (2011), "How international organizations rule the world: the case of the financial action task force on money laundering", Journal of International Organization Studies, Vol. 2, pp. 50-67. 
Mitsilegas, V. (2003), Money Laundering Counter-Measures in the European Union: A New Paradigm of Security Governance versus Fundamental Legal Principles, Kluwer Law International BV, Zuidpoolsingel.

Mitsilegas, V. and Vavoula, N. (2016), "The evolving EU AML regime: challenges for fundamental rights and the rule of law", Maastricht Journal of European and Comparative Law, Vol. 23 No. 2, pp. 261-293.

Mitsilegas, V., Alldridge, P. and Cheliotis, L. (2015), Globalisation, Criminal Law and Criminal Justice: Theoretical, Comparative and Transnational Perspectives, Bloomsbury Publishing, London.

Concept of money

laundering

Mugarura, N. (2016a), "Does the broadly defined ambit of money laundering offences globally, a recipe for confusion than clarity?", Journal of Money Laundering Control, Vol. 1.

Mugarura, N. (2016b), The Global AML Regulatory Landscape in Less Developed Countries, Routledge.

Paunović, N. (2019), "Terrorist financing as the associated predicate offence of money laundering in the context of the new EU criminal law framework for the protection of the financial system", $E U$ and Comparative Law Issues and Challenges Series (ECLIC), Vol. 3, pp. 659-683.

Pol, R.F. (2018), “AML effectiveness: assessing outcomes or ticking boxes?”, Journal of Money Laundering Control, Vol. 21 No. 2.

Pol, R.F. (2020), "AML: the world's least effective policy experiment? Together, we can fix it", Policy Design and Practice, Vol. 3 No. 1, pp. 73-94.

Proceeds of Crime Act (2002), UK.

Rusanov, G. and Pudovochkin, Y. (2018), "Money laundering and predicate offenses: models of criminological and legal relationships", Journal of Money Laundering Control, Vol. 1.

Schneider, F. (2008), "Money laundering and financial means of organized crime: some preliminary empirical findings", Paolo Baffi Centre Research Paper.

Sergi, A. (2015), "Organised crime in English criminal law: lessons from the United States on conspiracy and criminal enterprise", Journal of Money Laundering Control, Vol. 18 No. 2, pp. 182-201.

Slot, B. and Swart, D.L. (2019), Assessing the Outcomes of AML Policies, Ambitions and reality, New York, NY.

Stessens, G. (2000), Money Laundering: A New International Law Enforcement Model, Cambridge University Press, Cambridge.

Unger, B. (2013), "Money laundering regulation: from Al capone to Al qaeda”, Research Handbook on Money Laundering, Edward Elgar Publishing New York, NY, pp. 19-32.

Unger, B., Ferwerda, J., VAN DEN Broek, M. and Deleanu, I. (2014), The Economic and Legal Effectiveness of the European Union s AML Policy, Edward Elgar Publishing, New York, NY.

United Nations Convention against Corruption (2021), "United nations office on drugs and crime convention against corruption”, available at: www.unodc.org/unodc/en/treaties/CAC/ (accessed 4 January 2020).

United Nations Convention against Illicit Traffic in Narcotic Drugs and Psychotropic Substances (1988), "United nations office on drugs and crime", available at: https://www.unodc.org/unodc/ en/treaties/illicit-trafficking.html?ref=menuside (accessed 3 January 2020).

Vervaele, J. (2013), "Economic crimes and money laundering: a new paradigm for the criminal justice system?", Research Handbook on Money Laundering, Edward Elgar Publishing, New York, NY.

Williams, C. (2016), An Analysis of the Critical Shortcomings in South Africa's AML Legislation, University of the Western Cape, Western Cape.

Zoppei, V. (2015), "Money laundering: a new perspective in assessing the effectiveness of the AML regime", The European Review of Organised Crime, Vol. 2, pp. 130-148.

Zoppei, V. (2017), “The german law-making process: tracing legislative intents”, AML Law: Socio-Legal Perspectives on the Effectiveness of German Practices, Springer, New York, NY. 
JMLC 24,4

\section{Further reading}

Crimes and Criminal Procedure US.Code 18. USA.

FATF (2019), "Who we are", Financial Action Task Force, available at: www.fatf-gafi.org/about/ (accessed 19 December 2019).

United Nations Convention against Transnational Organized Crime and the Protocols Thereto "United nations office on drugs and crime", available at: www.unodc.org/unodc/en/organized-crime/ intro/UNTOC.html (accessed 4 January 2020).

\section{Corresponding author}

Muhammad Saleem Korejo can be contacted at: saleem.korejo@iba-suk.edu.pk

For instructions on how to order reprints of this article, please visit our website: www.emeraldgrouppublishing.com/licensing/reprints.htm

Or contact us for further details: permissions@emeraldinsight.com 